\title{
Research Paper Commercialization of meat production and marketing practices of garole sheep in West Bengal
}

See end of the paper for authors' affiliations

Correspondence to :

\section{Arnab Roy}

Department of Agricultural Economics, University of Agricultural Sciences (G.K.V.K.), Bengaluru (Karnataka) India Email : royarnab_94@ rediffmail.com
Paper History :

Received : 10.09.2018;

Revised : 16.01.2019;

Accepted : 26.01.2019
ABSTRACT : A study conducted in West Bengal elicits sheepmeat production cost and marketing. Two districts South 24-parganas (Sunderban region) and Kolkata were selected because in these two districts garole sheep were dominating against local breed. The data permit examination of goat meat demand of ethnic populations and the diversity among the states surveyed. Market value analysis of sheep reveals thatat less than 3 months of age, the garole sheep with weight of less than $15 \mathrm{~kg}$ have market value of Rs. 3500 to Rs. 5000 where 23.33 per cent of rearers prefer to sell their sheep at this stage.The major income was obtained from the sale of sheep (which includes sale of lamb, rams and adult ones). The average numbers of animals sold are 7 garole sheep per year and the net returns obtained Rs.18,620 per flock per year. The study also examined the determinants of profitability of sheep marketing in the study area. Data generated were analysed using descriptive statistics (tables, frequencies, percentages and means) and regression analysis. However, average price of feed, average price of shed and average price of commission charges) were significant at 1 per cent level of significance and also had a direct relationship with the profit from sheep marketing. Price of labour and price of transportation are negatively related with the profitability of marketing of sheep. Susceptibility to disease were the important determents for discouraging sheep farming followed by unavailability of breed and lack of interest towards sheep rareing.

KEY WORDS : Garole sheep, Lamb, Regression analysis, Profitability, Breed

How To Cite This PAPer : Roy, Arnab and Venkataramana, M.N. (2019). Commercialization of meat production and marketing practices of garole sheep in West Bengal. Internat. Res. J. Agric. Eco. \& Stat., 10 (1) : 8-13, DOI : 10.15740/HAS/IRJAES/10.1/8-13. Copyright@ 2019: Hind Agri-Horticultural Society. 